\title{
KEMATIAN MENURUT LOUIS LEAHY
}

\section{Wawaysadhya}

Fakultas Ushuluddin dan Humaniora

UIN Walisongo Semarang

Email: sadhyawaway@walisongo.ac.id

\begin{abstract}
This paper discusses "death" according to Louis Leahy's thoughts. It is interesting since he is a theologian as well as an academician who has produced many works on humans and human philosophy. Therefore, "death", which is commonly approached by using religious and scientific perspectives, investigated $b$ Leahy using $a$ philosophical perspective. The discussion of Leahy's thoughts in this paper is expected to enrich the philosophical thought and discourse regarding the "death" issue. Hence, "death" would no longer be understood merely as a definition stated in various literature, instead, its meaning could be more understood as an event that must be experienced by every human being.
\end{abstract}

Keywords: Death, Louis Leahy, Philosophical Perspective, Human Being

\begin{abstract}
Abstrak
Tulisan ini membahas mengenai "kematian" menurut pemikiran Louis Leahy. Menjadi menarik karena ia adalah seorang teolog yang juga akademisi dengan banyak karya mengenai manusia dan filsafat manusia. Apabila selama ini "kematian" pada umumnya dibahas dalam lingkup religius maupun ilmiah, Leahy membahas "kematian" dalam perspektif filosofis. Diharapkan pembahasan mengenai pemikiran Leahy dalam tulisan ini dapat semakin memperkaya perenungan dan diskursus kefilsafatan terkait kematian. Dengan demikian, memahami "kematian" bukan lagi hanya sekedar definisi yang dijumpai dalam berbagai literasi, tetapi lebih dari itu adalah memahami makna "kematian" sebagai peristiwa yang akan dialami oleh setiap manusia.
\end{abstract}

Kata kunci: Kematian, Louis Leahy, Perpektif Filosofis, Manusia 


\section{PENDAHULUAN}

Pada salah satu kuliah filsafat di jenjang S1, seorang Dosen pernah melontarkan satu pertanyaan pada para Mahasiwa, yaitu "Apakah yang paling dekat dengan Anda?" Seluruh mahasiswa diminta memberikan jawaban. Tentulah bermacam-macam jawaban dari para mahasiswa yang baru saja lulus dari Sekolah Menengah Atas tersebut. Beberapa dari mahasisw menjawab orang tua, beberapa menjawab Tuhan, bahkan ada yang menjawab teman yang duduk di bangku sebelah. Semua meyakini jawabannya sebagai jawaban yang paling tepat. Namun semua menjawab dengan jawaban yang seharusnya ditanyakan dengan pertanyaan 'Siapa' dan bukan 'Apa', jelaslah ada kekeliruan atas jawaban-jawaban yang diberikan. Lalu dosen tersebut pada akhirnya menjawab pertanyaan yang beliau lontarkan, ia berkata: "Yang paling dekat dengan Anda adalah kematian".

Pertanyaan tersebut adalah sebuah pertanyaan metafisis. Manusia seringkali mengabaikan kematian, yang sesungguhnya selalu berada di sekitarnya. Kematian, berasal dari kata 'mati', yang dalam Kamus Besar Bahasa Indonesia (KBBI) diartikan sebagai: 1) sudah hilang nyawanya; tidak hidup lagi. 2) tidak bernyawa; tidak pernah hidup. 3) tidak berair (tt mata air, sumur, dsb). 4) tidak berasa lagi. 5) padam (tt lampu, api, dsb). ${ }^{1}$

Mengacu pada pengertian yang dimuat dalam KBBI, maka 'mati' sebagai predikat pada penggunaan kalimat dapat dilekatkan pada makhluk hidup maupun benda mati. Sehingga kata 'mati' tidak melulu menunjukkan 'ke-tidak hidup-an'. Namun demikian, manusia adalah satu-satunya makhluk yang dimungkinkan dan mampu untuk memikirkan tentang kematian. Steve Jobs, seorang CEO perusahaan gadget ternama, pernah melakukan sebuah renungan tentang kematian yang ia sisipkan diantara pidatonya setelah ia divonis menderita kanker, berikut penggalan pidato Steve Jobs: ${ }^{2}$

"No one wants to die. Even people who want to go to heaven don't want to die to get there. And yet, death is the destination we all share. No one has ever escaped it, and that is how it should be, because death is very likely the single best invention of life. It's life's change agent. It clears out the old to make way for the new."

Kutipan tersebut merupakan refleksi Steve Jobs tentang kematian. Dapat dilihat bahwa ia memilih untuk menaruh respon positif sekaligus pasrah terhadap kematian. 
Sebuah sikap yang dilandasi kesadaran bahwa tak ada satu pun yang bisa menghindarkan diri dari kematian. Perbincangan tentang manusia, tentu saja akan mengarah dan sangat mungkin berakhir dengan perbincangan tentang kematian.

Perbincangan tentang kematian memang bukanlah hal yang sederhana baik karena ketidakjelasan yang disebabkan oleh ketiadaan pengalaman individu, maupun dikarenakan subjektivitas perasaan yang timbul akibat melihat kematian manusia lain. Gambaran tentang kematian secara utuh yang tak mampu dibahasakan menyebabkan sebuah kesepakatan terhadap adanya misteri tentang kematian yang sekaligus merupakan sebuah problem perennial. Kematian selamanya selalu menyisakan pertanyaan tak terjawab bagi manusia, kendati ia adalah hal yang paling dekat dengan kehidupan. Oleh karena itu dapat dikatakan bahwa bagi semua yang hidup, mati adalah keniscayaan, namun kematian adalah misteri.

Dengan demikian, kematian hanya mampu untuk dipahami melalui nalar, rasio, melalui proses analisis yang diawali dari pengamatan dan pengumpulan data. Filsafat manusia sebagai cabang dari epistemologi, membicarakan kematian sebagai salah satu pembahasan pokok. Banyak filsuf besar yang telah membahas perihal kematian dari beragam perspektif.

Louis Leahy, seorang dosen sekaligus tokoh filsafat kontemporer, yang dalam sebuah situs ensiklopedia internasional sudah diakui sebagai seorang filsuf, menaruh perhatian yang cukup besar perihal kematian. Leahy memiliki cukup banyak karya yang membicarakan mengenai kematian. Oleh karena itu, tulisan ini membahas pemikiran filosofis dari Louis Leahy tentang kematian.

\section{BIOGRAFI DAN KARYA}

Louis Leahy adalah salah satu pengajar di Sekolah Tinggi Filsafat (STF) Driyarkara, Jakarta. Ia dilahirkan di Queebeq, Kanada pada tanggal 19 Agustus 1927. Leahy merupakan seorang imam dan misionaris dari Serikat Jesuit, ${ }^{3}$ yang menyelesaikan Sekolah Menengah Pertama dan Sekolah Menengah Atas di Kolese Serikat Jesuit (Kolese Garnier) di Kanada. Di sekolah tersebut ia dihadapkan pada dua plihan kurikulum yaitu teologi dan filsafat, namun ia memilih mendalami filsafat yang menurutnya lebih menarik dan relevan sepanjang masa, karena masalahmasalah fundamental yang berasal dari lubuk hati manusia dan intelegensi manusia 
dari semua kebudayaan secara hakiki bersifat filosofis. ${ }^{4}$ Louis Leahy meninggal dunia pada tahun 2012 .

Karya-karya ilmiah yang ditulis oleh Louis Leahy berupa artikel-artikel dan buku-buku. Karya-karya yang ditulis dalam bentuk artikel antara lain:

1) "Filsafat Ketuhanan", dalam Orientasi, XIII, Kanisius, Yogyakarta, 1981.

2) "Sains dan Eksistensi Allah: suatu problematika baru" dalam Orientasi, XVI, Yogyakarta, 1984.

3) "Masalah Kejahatan", dalam Basis, no. XXXV-2, 1986.

4) "Kematian: sebuah akhir atau permulaan?", dalam Melintas, Bandung: Fakultas Filsafat Universitas Katolik Parahyangan, 1988.

5) "Refleksi Kristis Terhadap Ateisme", dalam Rohani, no. 12, Desember 1988.

6) "Perihal Makna Hidup", dalam dalam Zaman Teknologi Menantang Pewartaan Iman, (Orientasi Baru No. 3), Kanisius, Yogyakarta, 1989.

7) "Human Mind and Ultimate Reality", dalam Ultimate Rality and Meaning, 7, 1984.

Beberapa buku yang merupakan karya Leahy yang telah diterbitkan antara lain:

1) Ou est L'Eglise? Edisi Bellarmin, Montreal, 1959.

2) Dynamisme voluntaire et jugement libre. Edisi Desclee-de-Brouwer, BrugesParis, 1963.

3) L'ineluctable Absolu. Edisi Desclee-de-Brouwer, Bruges-Paris, 1965

4) Pantheisme, Action, Omega, chez Teilhard de Chardin, (Editing dan Kata Pengantar oleh pengarang). Edisi Desclee-de-Brouwer, Bruxelles-Paris, 1967.

5) Chemins de l'esprit vers l'Etre. Edisi Desclee-de-Brouwer dan Bellarmin, Bruxelles-Paris-Montreal, 1969.

6) Con Nguoi va van-de Thuong De. Edisi Giao Hoang Hpc Vien Thanh Pio X, Dalat, 1974.

7) L'homme et l'Absolu. Edisi dari L'Institut Superieur de Philosophie Canisius, Kinshasa, 1979.

8) Hay La Huyen Thoai. Edisi Giao Hoang Hoc Vien Thanh Pio X, Dalat, 1974.

9) Voies ouvertes sur Dieu. Edisi dari L'Institut Superieur de Philosophie Canisius, Kinshasa, 1979. 
10) L'homme, ce mystere. Pour une philosophie de l'homme. Edisi dari L'Institut Superieur de Philosophie Canisius, Kinshasa, 1981.

11) Masalah Ketuhanan Dewasa Ini. Jilid I dari: Manusia di hadapan Allah. Kanisius (Yogyakarta) dan BPK Gunung Mulia (Jakarta), 1984, 1990.

12) Manusia, Sebuah Misteri. Sintesa Filosofis tentang Makhluk Paradoksal, Penerbit Gramedia, Jakarta. Edisi pertama, 1984, 1985. Edisi kedua, yang diperbaharui, 1989.

13) Aliran-aliran Besar Ateisme, Penerbit Kanisius (Yogyakarta), dan BPK Gunung Mulia (Jakarta), 1985, 1990, 1992.

14) Kosmos, Manusia dan Allah. Jilid III dari: Manusia di hadapan Allah, Penerbit Kanisius (Yogyakarta), dan BPK Gunung Mulia (Jakarta), 1986.

15) Esai Filsafat Untuk Masa Kini. Telaah Masalah Roh-Materi Berdasarkan Data Empiris Baru, Penerbit Pustaka Utama Grafiti, Jakarta, 1991.

\section{CORAK PEMIKIRAN FILSAFAT}

Corak pemikiran Leahy dapat digambarkan dalam berbagai pendapatnya terkait dengan realitas yang ada. Subbab ini membahas sekilas pandangan Leahy tentang manusia.

Manusia adalah makhluk yang terbentuk atas susunan jiwa dan badan, atau jasmani dan roh. Manusia dilengkapi dengan objektifitas, pemikiran dan kebebasan menerima serta berkreasi, sehingga mampu menampakkan diri sebagai pribadi. ${ }^{5}$ Leahy menganggap pentingnya pembahasan tentang manusia melalui perspektif filosofis yang tersistematis dalam sebuah pemikiran filsafat manusia dengan beberapa alasan, sebagai berikut:

1. Manusia adalah makhluk yang mempunyai kemampuan istimewa beserta hak yang istimewa sampai batas tertentu.

2. Manusia memiliki tugas menyelidiki hal-hal secara mendalam.

3. Manusia memiliki kesadaran bahwa manusia berbeda dengan makhluk lainnya. Salah satu perbedaannya ialah bahwa manusia dilengkapi dengan tanggung jawab.

Dalam melakukan perenungan tentang hakikat manusia, maka kita akan sampai pada pertanyaan 'siapakah pencipta manusia?" ${ }^{6}$ Ada banyak ilmu-ilmu lain yang juga membahas manusia dengan sudut pandang yang berbeda. Namun 
demikian, dengan memahami filsafat manusia maka pengetahuan manusia tentang hakikat dirinya tentu saja akan menjadi lebih mendalam.

Manusia adalah makhluk paradoksal. ${ }^{7}$ Paradoksal dalam konteks ini adalah sifat yang seolah-olah berlawanan atau bertentangan tetapi pada dasarnya mengandung sebuah kebenaran. ${ }^{8}$ Manusia disebut paradoksal karena tersusun atas roh dan badan, bersifat subsitens dan terbuka, serta bereksistensi. Manusia senantiasa mencari jawaban atas setiap pertanyaan mengenai dirinya dan realitas di sekitarnya.

Keberadaan manusia lazim dijelaskan dengan cara memperbandingkan perbedaan antara manusia dan binatang. Susunan genetik, kemampuan-kemampuan motorik, afektif, serta berbagai indikator lain yang digunakan oleh manusia untuk membedakan dirinya dengan binatang. Salah satu buktinya adalah munculnya tesis penyebutan manusia sebagai animal symbolicum. Pada dasarnya, manusia memang memiliki kesamaan dengan makhluk hidup lain, baik binatang maupun tumbuhan. Akan tetapi, manusia tetap memiliki kelebihan dibandingkan dengan makhluk hidup yang lain.

Kodrat esensial makhluk hidup adalah sebuah substansi natural yang terbentuk dari badan dan jiwa, dengan organ yang menyusun kesatuan kompleks. ${ }^{9}$ Kodrat esensial tesebut dalam diri manusia dilengkapi dengan kesadaran terhadap dirinya. Upaya pencarian jati diri manusia merupakan hal yang paling membedakan antara manusia dan binatang. Pada saatnya, kesadaran dan pencarian jati diri manusia akan mengantarkan manusia pada pemahaman tentang hakikat dirinya.

Kesadaran manusia akan dirinya dan upaya pencarian jati diri manusia merujuk pada rumusan akan penyusunan manusia. Manusia tersusun atas jiwa dan badan, serta dilengkapi dengan beberapa karakteristik pembeda. Karakteristik manusia memberikan ciri khusus bagi manusia sehingga membedakan manusia dengan makhluk lain. Karakteristik manusia itu selanjutnya berkembang seiring berjalannya waktu.

\section{- Jiwa dan Badan}

Jiwa adalah bagian inti dari hidup manusia dan tidak bersifat materi serta berfungsi untuk mengenali dan menemukan segala signifikansi kehidupan. Jiwa yang tak dapat ditangkap secara langsung dengan indra manusia, akan menampakkan gejalanya melalui badan yang bersifat indrawi sehingga memungkinkan untuk merealisasikan kehadiran jiwa. Jiwa dan badan adalah suatu kesatuan esensial yang 
solider satu sama lain. Jiwa tidak dapat dipahami sebagai unsur yang terpisah dari badan jasmani, karena keduanya tidak dapat dipisahkan. Badan bukan semata-mata suatu wadah untuk membatasi jiwa, tetapi badan merupakan sarana eksistensi manusia. ${ }^{10}$

Jiwa merupakan bentuk spiritual dari badan, sehingga seringkali muncul pertanyaan terkait dengan keberadaan jiwa sering muncul, misalnya "dimana letak jiwa jika ia bersama dengan badan?" Jawaban terkait dengan pertanyaan tersebut secara singkat telah diungkapkan oleh Leahy, ${ }^{11}$ bahwa jiwa berada di dalam setiap bagian dari badan dan sekaligus utuh di dalam keseluruhannya. Letak jiwa dalam suatu badan tidak berada seperti titik pada sebuah kertas, melainkan berada di setiap sudut badan, sebagai bagian setiap detil keutuhan badan. Jiwa adalah sebuah idea yang berada pada puncak hirarki yang dimiliki manusia.

Secara tidak langsung, Leahy menyetujui konsep dualisme jiwa dan badan yang digagas oleh Plato. Menurut Leahy, keberadaan jiwa adalah nyata, namun hanya dapat diketahui di dalam -melalui- badan. Jiwa memiliki eksistensi dan bersifat unggul, dan demikian juga dengan badan. Badan ada sejurus dengan jiwa, tetapi 'ada' yang berbeda. Jiwa dan badan hendaknya menyatu menjadi suatu susunan manusia yang harmonis.

Leahy menganalogikan hubungan antara jiwa dan badan seperti harmonisasi musik dari permainan kecapi. Muncul bentuk baru harmonisasi musik kecapi, namun kemunculan yang baru itu tidak serta merta menghilangkan peran dari kedua unsur pembentuknya, yakni kecapi dan musik. Musik dari kecapi adalah jiwa, dan kecapi itu sendiri adalah badan, seperti proses terciptanya manusia. Untuk membentuk suatu realitas baru maka jiwa dan badan perlu berbaur dan menghilangkan hakikatnya masing-masing yakni, manusia yang hidup sepenuhnya. Hubungan antara badan dan jiwa tidak dipahami dalam pengertian penyatuan, melainkan kesatuan. ${ }^{12}$

Leahy selanjutnya menjelaskan bahwa dualisme yang dimaksud tidaklah sama dengan yang digagas oleh Plato. Konsep dualisme Plato menempatkan jiwa lebih tinggi daripada badan, dimana badan hanyalah sarana bertindak sementara jiwalah mengeksekusi pilihan. Leahy tidak setuju pada pandangan tersebut dengan anggapan bahwa badan juga berperan dalam pengambilan keputusan atau menentukan kebijakan. Lebih lanjut ia menjalaskan bahwa jiwa juga berperan dalam tindakan yang dilakukan badan, yakni memberikan arah pada tindakan yang 
dilakukan oleh badan melalui sarana 'mata batin' dan naluri. Dalam hal ini, jiwa datang melalui seruan hati yang seringkali disadari manusia ketika diperhadapkan dengan pilihan-pilihan. Dalam menentukan pilihan, terkadang manusia membutuhkan tidak hanya logika tetapi juga bantuan 'mata batin'.

Berdasarkan pada pembahasan tersebut maka hubungan jiwa dan badan dapat dipahami dalam uraian sebagai berikut: jiwa dan badan adalah hal yang berbeda, tetapi merupakan penyusun utama eksistensi manusia, dimana keduanya tidak saling mereduksi. Badan merupakan materi sebagai sarana pengejawantahan spiritualitas jiwa yang terbatas oleh ruang, dimana jiwa tersebut memenuhi ruang.

\section{ANALISA PEMIKIRAN LEAHY TENTANG KEMATIAN}

\section{- Ketakutan Akan Kematian}

Terdapat dua macam pandangan besar tentang ketakutan terhadap kematian. ${ }^{13}$ Pertama, pandangan yang berpendapat bahwa manusia dapat menerima kenyataan akan kematian dikarenakan adanya harapan akan kebakaan personal. Kedua, yaitu pandangan kepercayaan terhadap tidak adanya kehidupan baka, dan meski demikian manusia dapat mengatasi ketakutan akan kematian itu.

Louis Leahy dalam salah satu bukunya, yang dipulikasi pada 1998, membicarakan tentang kelompok dengan pandangan yang pertama, yaitu yang mengatasi ketakutan dengan keyakinan akan adanya kebakaan jiwa. Esensi jiwa tidak bisa terkena pembusukan karena jiwa tidak memiliki unsur-unsur material. Jiwa manusia memiliki sifat spiritual, yaitu apa yang disebut dengan transendensi terhadap tubuh, sehingga penalaran filosofis mengenai kematian erat sekali hubungannya dengan proses kreatif yang dilakukan oleh Tuhan. ${ }^{14}$

Leahy juga memberikan argumen-argumen yang dipakai untuk membahas masalah kekekalan jiwa, beberapa diantarnya yaitu:

1. Argumen hasrat untuk hidup. Hasrat diibaratkan dengan kita yang selalu berjalan dalam hidup namun kita tidak pernah merasa seakan-akan sudah melewati jalan itu sehingga sudah tiba saatnya meninggalkan jalan itu. Ada satu sisi di dalam diri kita, kita abadi.

2. Argumen hasrat kepada kebahagiaan. Jiwa harus diperlengkapi dengan kehidupan setelah mati karena kehidupan di dunia materi seringkali tidak 
sempurna. Jadi, kemungkinan adanya kebahagiaan total yang drindukan oleh semua orang menuntut kekekalannya.

Sedangkan pandangan dari kelompok kedua yang mengatasi ketakutan akan kematian tanpa adanya keyakinan akan kebakaan jiwa diwakili oleh beberapa pandangan, ${ }^{15}$ yaitu:

1. Epicurus dan Pengikutnya. Menurut Epicurus, kematian tidak perlu ditakuti karena kematian sama halnya dengan tidur, yaitu hilangnya kesadaran, sehingga kematian tidak menyakitkan.

2. Kaum Stoic. Seneca mengatakan bahwa manusia harus memikirkan kematian dengan cara yang tepat, yaitu selalu mengingatkan diri sebagai bagian dari alam dengan peranan yang harus diterima.

3. Spinoza. Manusia harus mengalihkan perhatian dari kematian dengan cara memusatkan perhatian pada kehidupan. Dengan demikian ketakutan akan kematian dapat diusir.

\section{- Kematian dan Prosesnya}

Terdapat lima tahapan kematian yang diungkapkan oleh Elisabeth KublerRoss, M. D. ${ }^{16}$ Tahapan-tahapan itu dirumuskan berdasarkan hasil observasinya dari para penderita penyakit kanker, yaitu: a) tahap penyangkalan dan menyendiri, b) tahap marah, c) tahap tawar menawar, d) tahap depresi, e) tahap menyerah dan pasrah.

Tahapan-tahapan digagas oleh Kubler-Ross berbicara mengenai kondisi khusus tentang kematian yang datang pada kondisi orang-orang yang telah didiagnosis akan mati. Permasalahannya adalah bagaimana dengan orang-orang yang tidak mendapatkan vonis kematian dari dokter ataupun manusia lain selain dirinya? Bagaimana proses kematian bagi orang-orang yang disebut sebagai kematian biasa atau normal tanpa penyakit.

Leahy mempunyai pandangan sendiri mengenai proses kematian ini dan mengungkapkannya dalam dua tahap yang sejatinya satu proses saja. Leahy, ${ }^{17}$ menyebut tahap pertama dengan istilah, 'kematian yang ditantang'. Tahapan ini kemudian berproses menjadi kepasrahan yang menyebabkan kematian tidak lagi terasa menakutkan.

Leahy menyadari bahwa rasa ingin, atau yang ia disebut sebagai perasaan menantang, bukanlah sebuah obsesi karena obsesi hanya bisa berbentuk ketakutan. 
Misalnya, ketakutan pantologis terhadap kematian. Ketakutan semacam ini sebenarnya merupakan konsekuensi logis yang memang harus dihadapi secara manusiawi oleh setiap orang. Namun lagi-lagi permasalahan kesehatan dan kondisi prima yang seharusnya dimiliki oleh seorang manusia menjadi taruhan sehingga menghadapi kematian tidak harus dirasakan dalam bentuk ketakutan. Leahy, lebih dalam, mengungkapkan bahwa mempertimbangkan kematian sama halnya dengan mempertimbangkan kehidupan, karena pada dasarnya kedua hal ini saling berhubungan terutama bagi golongan orang yang beriman. ${ }^{18}$

Melalui penjelasan ini, Leahy menyadari bahwa bagi hampir seluruh manusia, kematian mewujud dalam bentuk ketakutan. Namun demikian, kematian pasti datang kepada setiap orang, sehingga salah satu jalan untuk menghadapi kematian adalah dengan menantang kematian itu sendiri. Menantang dalam artian mengumpulkan semua keberanian untuk mempertimbangkannya secara matang, sehingga pada saat yang sama kita juga mempertimbangkan kehidupan yang telah dijalani.

\section{- Saat Kematian}

Setelah menjalani tahapan menuju kematian yang harus dipertimbangkan, sebagaimana halnya mempertimbangkan kehidupan, maka ada pula tahapan ketika kematian itu benar-benar terjadi. Dalam pemikiran Leahy, indikator tahapan tersebut ialah bahwa untuk menghadapi kematian perlu suatu keberanian. Keberanian itu merupakan keberanian yang sama pada saat kita menghadapi kehidupan. Maka sesungguhnya yang ingin disampaikan oleh Leahy adalah kematian adalah pada saat kita menjadi pasrah pada apa yang akan hilang.

Secara biologis tentu akan sangat banyak yang bisa menjelaskan bagaimana kira-kira saat kematian ini akan tiba. Hal ini sebagaimana dijelaskan dalam konsep kematian secara klinis, yakni keadaan dimana kegiatan pernafasan, jantung, dan reaksi otak kelihatan berhenti. Dengan memberikan waktu antara 5 (lima) hingga tiga puluh menit sebagai waktu tenggang sehatnya otak manusia. ${ }^{19}$

Namun bagaimana dengan pandangan-pandangan yang bersifat kejiwaan dalam memahami kematian ini? Apakah jiwa manusia tidak memiliki peran sedikitpun dalam menentukan dan menemukan kematian ini? Leahy, sebagai seorang pemikir yang mempercayai kekekalan jiwa, tentu saja menilai kematian bukan akhir dari segala-galanya. Apabila badan, sebagaimana yang diakui oleh Plato, merupakan 
kerangkeng kebebasan hakiki manusia maka kematian adalah zaman permulaan dan kebebasan. Maka kematian, dalam batasan terma-nya merupakan sesuatu yang berhubungan dengan fisik jasmaniah belaka.

\section{- Arti Kematian}

Lalu apa sebetulnya yang disebut kematian? Ada tiga pandangan utama untuk menjelaskan tentang kematian. Pertama, pandangan menurut Heidegger, mengungkapkan kematian sebagai sesuatu yang merupakan perpanjangan-tangan dari proses hidup manusia yang memang tidak berkesudahan dalam perangkap "belum". Oleh karena itu hidup menurut Heidegger adalah sebuah proses menuju kematian. Kemudian menurut Sartre, kematian adalah sekonyong-konyong yang bersifat buta dan sangat absurd karena ia bersifat pasti namun tidak menyediakn pilihan. Sedangkan menurut Jaspers, ${ }^{20}$ kematian adalah akhir dari proses hidup karena manusia telah berada pada kondisi pemenuhan.

Dari ketiga pandangan tersebut, dapat disimpulkan bahwa kematian, pada dasarnya, dapat dipandang sebagai sesuatu yang subjektif. Kematian tidaklah bersifat universal sebagaimana dipahami oleh banyak orang. Tentu saja pandangan yang dikemukakan ketiga tokoh tersebut dipengaruhi oleh cara pandang masing-masing tokoh terhadap kehidupan dan dunia ini.

Lalu bagaimana pandangan Leahy terhadap kematian? Sebagaimana yang telah sempat disinggung sebelumnya, kematian adalah sesuatu yang mesti dipertimbangkan. Leahy menyatakan bahwa pemikiran yang matang tentang kematian, pertimbangan, atau bahkan keberanian ketika menantang kematian bukanlah sesuatu yang menghancurkan kesadaran manusia. Hal yang menghancurkan kesadaran manusia, dalam kaitannya dengan kematian, justru jika kematian dianggap sebagai peniadaan dari hidup sendiri. ${ }^{21}$

Dengan demikian, maka sebenarnya Leahy sepakat dengan dua dari tiga filsuf di atas, yang memandang bahwa kematian itu bersifat pasti dan manusia menuju ke arahnya. Selain itu, dalam pandangan Leahy, manusia akan mati secara terhormat jika telah berhasil memikirkan, merancang dan mempertimbangkan secara matang tentang kematian. Demikian halnya yang terjadi bagi mereka yang berhasil menghadapi kematian dengan keberanian seperti yang terjadi pada diri para pahlawan dan martir. 
Secara filosofis, arti kematian menurut Leahy adalah sebuah proses yang menyadarkan manusia bahwa selama ini manusia tidak hidup dalam dunia yang diciptakannya sendiri. Pendapat tersebut senada dengan pandangan yang menyatakan bahwa manusia selalu berhutang akan eksistensinya kepada sesuatu yang berada di luar dirinya. Kematian membuat manusia menyadari dan menghadapi pegalaman dasar yang transenden yang berbeda dengan dunia, yang pada masa sebelumnya hal itu juga yang menciptakan eksistensi manusia. ${ }^{22}$

\section{- Refleksi Atas Kematian}

Bagaimanapun, kematian adalah kondisi yang sangat menakutkan dan mengancam kemapanan eksistensi manusia. Selamanya pengalaman akan kematian akan menjadi sebuah misteri bagi manusia yang masih hidup. Kematian, baik yang datang dalam bentuk normal maupun tidak normal, selalu saja memutus kehidupan manusia dengan sewenang-wenang. Kematian merampas seluruh skala nilai dalam kehidupan manusia.

Hampir semua manusia merasa kematian datang terlalu cepat, ketika kematian dialami oleh orang lain. Pada saat yang sama orang menyatakan bahwa seharusnya kematian belum datang dan belum memunculkan wujudnya. Pada posisi ini, pandangan Heidegger dalam memangang kematian cukup relevan. Bahkan ketika ia datang secara mendadak, apa yang dikatakan sebagai sebuah kematian, dimana kita selalu menuju kesana, setidaknya memberikan jawaban yang cukup jelas. ${ }^{23}$

Seluruh paham yang berbicara mengenai kematian juga dilambangkan dengan peristiwa kelahiran. Pada saat lahir, seorang bayi keluar dari batas-batas rahim ibunya. Dan dengan demikian ia harus meninggalkan sesuatu yang baginya bersifat protektif, akrab dan nyaman. Ia menjadi tidak terlindung lagi dan terancam. Pada waktu yang sama ia kemudian diperkenalkan dengan sebuah dunia yang baru dan relasi baru dengan dunia cahaya, persaudaraan dan cinta kasih manusia. Hal ini juga sama dengan kematian, ketika kehidupan diambil darinya, maka sebuah relasi baru tercipta dan sudah menantinya. ${ }^{24}$

Kondisi ini sungguh sangat solutif. Di tengah-tengah bayangan yang menakutkan tentang kematian Leahy menggambarkan sesuatu yang lebih mudah dipahami. Kematian adalah sebuah kelahiran yang datang setelah kematian. Kematian adalah pembukaan dunia baru yang kita tidak pernah tahu bagaimana bentuk dan kemungkinan keindahan yang ada di sana. Seperti halnya bayi yang, 
tentu saja, merasa gamang mendapatkan sebuah relasi baru dengan bertukarnya kegelapan rahim ibunya dengan dunia cahaya dan hangatnya cinta para manusia. Demikian halnya dengan kematian, seharusnya juga membuat timbulnya semacam kondisi dimana manusia dimungkinkan untuk menjumpai sesuatu yang lebih membebaskan dirinya.

\section{- Kematian Setiap Saat}

Konsep-konsep yang telah disampaikan di atas adalah semua yang bisa kita kemukakan sebagai manusia yang masih bisa membahas sesuatu dalam alam materi; sebagai manusia yang masih hidup dan belum didatangi oleh kematian. Namun, sebagaimana yang diungkapkan oleh Jaspers melalui teori Iman filosofisnya, ${ }^{25}$ manusia harus bersedia untuk merangkul misteri bahwa eksistensi manusia berasal dari yang lain. Oleh karena itu, ketika kematian datang manusia bisa mengandalkan hal lain yang bersifat transenden itu.

Kematian setiap saat adalah semacam penjelasan reflektif dalam melihat bagaimana sebuah akhir itu sebetulnya terkandung di dalam proses. Kematiankematian yang berada di dalam proses ini lah yang disebut sebagai keputusankeputusan final. Kematian pada hakikatnya adalah sesuatu yang langsung membusuk dan tidak dapat diulang, diperbaiki secara mutlak dan dirombak seperti semula. Maka apapun yang telah terjadi dan berakhir dalam kehidupan, sejatinya merupakan kematian. Setiap satu keputusn final dibuat, maka hal itu sebenarnya adalah kematian. Dengan demikian, dapat dipahami bahwa sebetulnya tidak ada kematian yang benar-benar mendadak, karena ketika seorang manusia sadar bahwa setiap saat adalah kematian baginya melalui keputusan final, maka kematian dalam artian keputusan paling finalpun telah ia rencanakan. ${ }^{26}$

Leahy membandingan pendapat tersebut dengan menggambarkannya dalam dua macam kondisi ${ }^{27}$ yaitu kematian dalam paham tradisional dan kematian dalam paham kosmis. Kematian dalam paham tradisional sebetulnya mirip dengan konsep kematian setiap saat yang melibatkan keputusan final. Bahwa seorang manusia diminta untuk mengenal dirinya dengan begitu mendalam sehingga pada gilirannya kelak maka ia bisa mendapatkan sebuah pengetahuan atau kesadaran intuitif akan dirinya secara langsung, yang berlangsung dalam hakikatnya sendiri.

Penjelasan yang diberikan oleh Leahy mengacu pada praktek-praktek yang dilakukan oleh orang-orang yang menganut paham asketis. Melalui praktek yoga 
mereka bisa memberitahu tentang out of the body experience yang jika kita artikan adalah keluar dari tubuh. Proses keluar dari tubuh ini tentu saja sangat identik dengan kematian. Pasalnya adalah praktek keluar dari tubuh ini dilakukan atau bisa dipraktekkan ketika kita masih hidup dan belum melewati titik pemberian keputusan paling final dari kehidupan ini. Maka seseorang yang melakukan praktek yoga akan sering mengalami kematian-kematian ${ }^{28}$ yang meskipun berbeda corak dengan konsep kematian setiap saat dalam kondisi keputusan final, namun secara mendasar kedua hal ini sangatlah mirip.

Sementara itu dalam pembahasan mengenai paham kosmis, Leahy mengungkapkan hal yang mirip dengan proses daur ulang. Kondisi dimana seorang manusia yang memiliki jiwa dan kemudian tercerai berai dengan kematian padahal jiwanya mengikut pada badannya. Paham ini diungkapkan oleh orang-orang yang mempercayai teori evolusi seperti Teilhard De Chardin dan Ladislas Boros. Penjelasan mengenai kondisi daur ulang ini adalah ketika jiwa yang bersatu dengan badan kemudian tercerai berai dan terputus pada banyak bagiannya, sejatinya akan kembali ke kosmos untuk menjadi sebuah realitas yang baru meskipun berbeda. Dengan demikian, kematian adalah sebuah hal yang terjadi berulang kali dan terjadi pada segala sesuatu yang ada di dalam alam semesta ini. ${ }^{29}$

\section{KESIMPULAN}

Berdasarkan penjelasan mengenai pandangan Leahy terhadap kematian terutama secara antropologi filosofis, dapat disimpulkan secara sederhana bahwa bagi Leahy hidup di atas bumi menuju ke arah kehidupan kekal. Namun kepercayaan akan akhirat tetap saja tidak dapat menanggalkan kematian dari sifat dramatisnya. Meninggalkan dunia berarti merasa direnggut dari orang-orang yang dicintai dan diandalkan. Namun ketakutan tersebut harus dilewati karena adanya keyakinan akan realitas obyektif yang menanti di seberang kematian. Oleh karena itu, kematian bukan sebuah tragedy melainkan peralihan jiwa dari dunia spasio-temporal kepada suatu hidup baru yang bentuk konkretnya tidak bisa dibayangkan. ${ }^{30}$

Dasar yang paling kuat dari keyakinan itu adalah kesetiaan pada Sang Pencipta. Walaupun demikian, kita tetap tinggal dalam ketidaktahuan mengenai bagaimana hidup dalam dunia akhirat terwujud secara konkret. Setidaknya manusia dapat memastikan hal-hal berikut. ${ }^{31}$ 
a. Kebahagiaan yang menanti pasti bersifat manusiawi, sesuai dengan struktur yang diberikanNya.

b. Kebahagiaan dariNya akan bersifat sosial, sebagaimana kodrat manusia.

c. Kebahagiaan kekal pasti tetap berdimensi jasmaniah, karena manusia bukan roh murni sebagaimana malaikat.

d. Manusia yang paradoksal kelak di akhirat akan mengambil bagian dalam kebaikan dan kesempurnanNya, sehingga beralih ke sikap penghadiran muka demi muka, yaitu merupakan arti dari Firdaus.

\section{Catatan Akhir}

1 “Pengertian Kata: Mati," accessed September 23, 2019, https://kbbi.web.id/mati .

2 Steve Jobs, "Commencement Address," accessed September 23, 2019, https://news.stanford.edu/2005/06/14/jobs-061505/.

${ }^{3}$ J. Sudarminta and S. P. Lili Tjahjadi, Dunia, Manusia, Dan Tuhan (Yogyakarta: Kanisius, 2008), 286.

${ }^{4}$ Sudarminta and Tjahjadi, 15-17.

${ }^{5}$ Louis Leahy, Manusia Sebuah Misteri: Sintesa Filosofis Tentang Makhluk Paradoksal (Jakarta: Gramedia, 1989), 28.

${ }^{6}$ Leahy, 1-2.

${ }^{7}$ Louis Leahy, Esai Filsafat Untuk Masa Kini (Jakarta: Pustaka Utama Grafiti, 1994), 182.

${ }^{8}$ Tim Penyusun, Kamus Besar Bahasa Indonesia (Jakarta: Balai Pustaka, 1988), 648.

${ }^{9}$ Leahy, Manusia Sebuah Misteri: Sintesa Filosofis Tentang Makhluk Paradoksal, 39.

${ }^{10}$ Louis Leahy, Misteri Kematian (Jakarta: Gramedia, 1998), 49.

${ }^{11}$ Leahy, 66-67.

${ }^{12}$ Leahy, 111.

13 Hardono Hadi, Jati Diri Manusia Berdasarkan Filsafat Organisme Whitehead (Yogyakarta: Pustaka Filsafat, 1996), 165.

${ }^{14}$ Louis Leahy, Siapakah Manusia? (Yogyakarta: Kanisius, 2001), 242-44.

${ }^{15}$ Hadi, Jati Diri Manusia Berdasarkan Filsafat Organisme Whitehead, 165-66.

${ }^{16}$ Hadi, 167-74.

${ }^{17}$ Leahy, Esai Filsafat Untuk Masa Kini, 53.

${ }^{18}$ Leahy, Misteri Kematian, 132.

${ }^{19}$ Hadi, Jati Diri Manusia Berdasarkan Filsafat Organisme Whitehead, 174.

${ }^{20}$ Hadi, 174-77.

${ }^{21}$ Leahy, Misteri Kematian, 135.

${ }^{22}$ Hadi, Jati Diri Manusia Berdasarkan Filsafat Organisme Whitehead, 177.

${ }^{23}$ Hadi, 178-79.

${ }^{24}$ Leahy, Siapakah Manusia?, 274.

${ }^{25}$ Hadi, Jati Diri Manusia Berdasarkan Filsafat Organisme Whitehead, 181.

${ }^{26}$ Hadi, 182.

${ }^{27}$ Leahy, Siapakah Manusia?, 272.

${ }^{28}$ Leahy, Misteri Kematian, 119-21.

${ }^{29}$ Leahy, Siapakah Manusia?, 272-73.

${ }^{30}$ Leahy, Misteri Kematian, 127.

${ }^{31}$ Leahy, 128. 


\section{DAFTAR PUSTAKA}

Hadi, Hardono. Jati Diri Manusia Berdasarkan Filsafat Organisme Whitehead. Yogyakarta: Pustaka Filsafat, 1996.

Jobs, Steve. "Commencement Address." Accessed September 23, 2019. https://news.stanford.edu/2005/06/14/jobs-061505/.

Leahy, Louis. Esai Filsafat Untuk Masa Kini. Jakarta: Pustaka Utama Grafiti, 1994.

_. Manusia Sebuah Misteri: Sintesa Filosofis Tentang Makhluk Paradoksal. Jakarta: Gramedia, 1989.

_. Misteri Kematian. Jakarta: Gramedia, 1998.

- Siapakah Manusia? Yogyakarta: Kanisius, 2001.

Penyusun, Tim. Kamus Besar Bahasa Indonesia. Jakarta: Balai Pustaka, 1988.

Sudarminta, J., and S. P. Lili Tjahjadi. Dunia, Manusia, Dan Tuhan. Yogyakarta: Kanisius, 2008. 